\title{
EFFECT of COMPETENCE, WORK PLACEMENT and ACHIEVEMENT on CAREER DEVELOPMENT (Study at BPN Madiun Municipality )
}

\author{
Tatik Mulyati $^{1)}$, Saraswati Budi Utami ${ }^{2)}$ \\ ${ }^{1.2)}$ Fakultas Ekonomi, Universitas Merdeka Madiun \\ email: tatikmulyati@unmer-madiun.ac.id
}

\begin{abstract}
The success of the organization in achieving its goals is supported by internal and external factors. To realize employee career development, the internal side must first receive attention. This study aims to determine the effect of competence, work placement and performance on the career development of employees of the National Land Agency (BPN) of Madiun City.The research method used is quantitative descriptive. The data used are primary data through questionnaires and secondary data. The population in this study were all permanent employees of 40 people. The research variable consists of independent variables, namely competence, work placement and performance, and the dependent variable is employee career development. Variables measured by Likert scale and data analysis techniques using multiple linear regression. Hypothesis testing uses $t$ test and $F$ test. The results of the study concluded that: 1) Competence affects employee career development; 2) Job placement does not affect employee career development; 3) Performance affects the career development of BPN employees in Kota Madiun.
\end{abstract}

Keywords: competence, work placement, work performance, career development

\begin{abstract}
Abstrak
Keberhasilan organisasi dalam mencapai tujuan didukung oleh faktor internal dan eksternal. Untuk mewujudkan pengembangan karir pegawai, sisi internal harus lebih dulu mendapat perhatian. Penelitian ini bertujuan untuk mengetahui pengaruh kompetensi, penempatan kerja dan kinerja terhadap pengembangan karir pegawai Badan Pertanahan Nasional (BPN) Kota Madiun.Metode penelitian yang digunakan adalah deskriptif kuantitatif. Data yang digunakan adalah data primer melalui kuesioner dan data sekunder. Populasi dalam penelitian ini adalah semua pegawai tetap sebanyak 40 orang. Variabel penelitian terdiri dari variabel bebas yaitu kompetensi, penempatan kerja dan kinerja, dan variabel terikatnya adalah pengembangan karier pegawai. Variabel diukur dengan skala Likert dan teknik analisis data menggunakan regresi linier berganda. Pengujian hipotesis menggunakan uji t dan uji F. Hasil penelitian menyimpulkan bahwa: 1) Kompetensi memengaruhi pengembangan karier pegawai; 2) Penempatan kerja tidak mempengaruhi pengembangan karir pegawai; 3) Kinerja memengaruhi pengembangan karir pegawai BPN Kota Madiun.
\end{abstract}

Kata kunci: kompetensi, penempatan kerja, prestasi kerja, pengembangan karir 


\section{A. PENDAHULUAN}

Manusia merupakan unsur terpenting dalam organisasi, meskipun berbagai faktor lain telah tersedia, tanpa ada peran manusia suatu organisasi tidak akan berjalan. Sumber daya manusia merupakan faktor terpenting dan peluang berharga dalam suatu instansi. Pencapaian kinerja pegawai secara optimal akan terwujud jika ada pengembangan kualitas sumber daya manusia yang terarah dan terkoodinasi dengan baik.

Tuntutan untuk mengelola sumber daya manusia juga diperkuat dengan terbitnya Undang-Undang Nomor 05 tahun 2014 tentang Aparatur Sipil Negara (ASN) yang berkomitmen melayani rakyat secara berintegritas moral dan bertanggung jawab. Sebagaimana moto Koprs Pegawai Negeri Republik Indonesia, ASN merupakan 'abdi negara', pelayan masyarakat. Undang-Undang tersebut disusun untuk menjamin perlindungan pegawai negeri sebagai sebuah profesi yang bertanggung jawab dalam melaksanakan kebijakan pemerintah secara efektif dan efisien serta memberikan pelayanan yang berkualitas kepada masyarakat. Dengan berkembangnya dunia kerja, pegawai bertugas sebagai perencana, pelaksana dan pengawas kegiatan yang telah dilakukan serta berperan aktif dalam mewujudkan tujuan. Kondisi ini mengisyaratkan bahwa pengembangan sumber daya manusia merupakan tuntutan yang tidak dapat dielakkan guna menjamin ketersediaan sumber daya manusia berkualitas sesuai tuntutan organisasi.

Dalam usaha pengembangan karir pegawai, banyak faktor yang perlu dipertimbangkan, antara lain kompetensi, penempatan kerja dan prestasi kerja. Kompetensi adalah kecakapan atau kemampuan memanfaatkan pengetahuan dan keterampilan kerja guna mencapai kinerja optimal. Selain kompetensi, faktor yang dapat memengaruhi pengembangan karir adalah penempatan kerja, yang diartikan sebagai proses penugasan atau pengisian pegawai pada tugas ataupun jabatan yang berbeda, sehingga harus dilaksanakan dengan berbagai perencanaan agar sumber daya manusia dapat bekerja lebih efisien dan efektif, untuk mengurangi tekanan akibat jabatan yang tidak sesuai (Dessler, 2005).

Kompetensi dan prestasi kerja merupakan perwujudan kesempatan mengembangkan diri. Setiap pegawai perlu untuk mempertimbangkan saat memilih pekerjaan atau menentukan arah karir. Pekerjaan yang sifatnya rutinitas dan tidak memberikan kesempatan kepada pegawai untuk mengembangkan diri, suatu saat akan tertinggal dan mungkin tidak sanggup mengikuti perubahan. Jika hal ini terjadi, pegawai akan mengalami stagnasi dalam karir, sehingga sangat diperlukan upaya mengembangkan diri dan karir(Mulyati, 2015).

Pengembangan karir merupakan sekumpulan tujuan pribadi dan gerakan strategis yang mengarah pada pencapaian prestasi yang tinggi dan kemajuan pribadi sepanjang jalur karir. Tujuan pengembangan karir secara umum adalah membantu karyawan memusatkan perhatian pada masa depan dalam organisasi atau perusahaan dan membantu karyawan mengikuti jalur karir yang melibatkan proses belajar secara terus-menerus. Hal ini berarti karyawan mendapat tanggung jawab, wewenang, dan jenis tugas yang semakin besar(Supardi, 2009). 
Pengembangan karir diartikan sebagai aktivitas yang dilakukan terusmenerus, usaha yang disusun oleh organisasi yang memiliki fokus pada pengembangan dan memperkaya sumber daya manusia di dalam organisasi dalam menerangkan kebutuhan karyawan dan organisasi(Paseki, 2013).

Kantor Badan Pertanahan Nasional Kota Madiun merupakan lembaga pemerintah nonkementerian yang berada di bawah Kementerian Agraria dan Tata Ruang yang bertanggung jawab kepada Presiden dan dipimpin oleh kepala (sesuai Peraturan Presiden No. 63 Tahun 2013); mempunyai tugas terutama dalam bidang pelayanan pertanahan, perijinan dan rekomendasi di bidang pertanahan, dituntut menjadi pengelola hubungan antara pusat dan daerah secara profesional.

Kian tingginya tuntutan publik terhadap mutu pelayanan birokrasi mengharuskan ASN membangun budaya kerja berlandaskan disiplin kuat, semangat melayani yang tinggi, transparan, dan akuntabel. Sudah selayaknya pegawai dituntut memiliki kompetensi dan prestasi dalam bekerja sehingga mampu melakukan pekerjaan secara efektif dan efisien yang pada gilirannya dapat mengembangkan karir secara optimal.

Badan Pertanahan Nasional Kota Madiun dalam mewujudkan pegawai profesional, dihadapkan pada permasalahan antara lain pertimbangan dalam penempatan pejabat belum terencana dengan baik, standar kompetensi belum diterapkan maksimal, pola pengembangan karir belum berjalan baik, penilaian prestasi kerja tidak transparan serta pelaksanaan diklat belum sepenuhnya sesuai tujuan.
Sementara, pegawai dituntut mengikuti perubahan jaman dengan adanya kemajuan teknologi dan komunikasi sehingga diharapkan mampu melayani masyarakat secara terbuka, berintegritas dan berkualitas. Aparatur Sipil Negara harus mampu bekerja secara cepat, responsif dan fleksibel. Untuk mewujudkan hal tersebut, Badan Pertanahan Nasional Kota Madiun harus didukung oleh pegawai yang memiliki kompetensi dan prestasi kerja tinggi(Syaharudin, Syah and Nurhardjo, 2018).

\section{B. METODE PENELITIAN}

Penelitian ini menggunakan metode deskriptif dan kuantitatif, bertujuan untuk mengetahui hubungan antara faktor kompetensi, penempatan kerja dan prestasi kerja dengan pengembangan karir pegawai di Badan Pertanahan Nasional Kota Madiun. Populasi penelitian ini adalah semua pegawai yang berjumlah 60 orang yang terdiri dari 40 merupakan ASN dan 20 lainnya merupakan pegawai tidak tetap. Sampel diambil 40 orang pegawai yang merupakan ASN, sehingga kesempatan untuk mengembangkan karir. Teknik pengumpulan data dilakukan melalui observasi, wawancara dan kuesioner.

\section{Definisi Operasional Variabel}

Definisi operasional variabel independen Kompetensi menurut Chung and Lo, (2007) memiliki indikator:

1) Pengetahuan;

2) Keterampilan;

3) Perangai atau sifat dan

4) Konsep diri.

Menurut Fitriaty dan $\operatorname{Ninik}(2015)$, indikator Penempatan Kerja adalah:

1) Pendidikan;

2) Pengetahuan kerja; 
3) Keterampilan kerja dan

4)Pengalaman kerja.

Menurut Astuti dan Bukhari(2018) indikator Prestasi Kerja adalah:

1) Kualitas kerja;

2) Kuantitas kerja;

3) Disiplin kerja;

4) Inisiatif dan

5) Kerjasama

Sedangkan variabel dependen pengembangan karir menurut Wirotomo dan Novita(2015) memiliki indikator:

1) Kesempatan melakukan sesuatu yang membuat pegawai senang;

2) Kesempatan mencapai sesuatu yang berharga;

3) Kesempatan memelajari hal-hal baru

4) Kesempatan mengembangkan kecakapan dan kemampuan.

Kuesioner dalam penelitian ini diukur menggunakan skala Likert dengan nilai atau skor tertinggi lima dan nilai terendah satu, sehingga data kualitatif menjadi data kuantitatif. Instrumen penelitian menggunakan kuesioner yang disebarkan kepada responden. Pernyataan dalam kuesioner berpedoman pada indikator-indikator variabel tentang kompetensi, penempatan kerja dan prestasi kerja terhadap pengembangan karir pegawai pada kantor Badan Pertanahan Nasional Kota Madiun dengan memilih salah satu alternatif jawaban yang disesuaikan. Setiap butir pertanyaan disertai lima jawaban dengan menggunakan skor. Instrumen penelitian selanjutnya dilakukan uji Validitas dan uji Reliabilitas untuk memastikan bahwa data yang diperoleh benar-benar valid dan mampu menggambarkan responden

\section{Teknik Analisis Data}

Teknik analisis dalam penelitian ini adalah regresi linier berganda, untuk mengetahui pengaruh variabel independen (X) kompetensi, penempatan kerja dan prestasi kerja terhadap pengembangan karir pegawai sebagai variabel dependen (Y). Persamaan regresi sebagai berikut :

$$
\mathrm{Y}=\mathrm{a}+\mathrm{b} 1 \mathrm{X} 1+\mathrm{b} 2 \mathrm{X} 2+\mathrm{b} 3 \mathrm{X} 3+\mathrm{e}
$$

Keterangan :

$$
\begin{array}{ll}
\mathrm{Y} & \text { : Pengembangan karir } \\
\mathrm{a} & \text { : Konstanta } \\
\mathrm{b} 1, \mathrm{~b} 2, \mathrm{~b} 3: & \text { Koefisien regresi } \\
\mathrm{X} 1 & \text { : Kompetensi } \\
\mathrm{X} 2 & \text { : Penempatan kerja ; } \\
\mathrm{X} 3 & \text { : Prestasi kerja } \\
\mathrm{e} & \text { : error }
\end{array}
$$

\section{Uji Asumsi Klasik}

Model regresi dapat digunakan untuk estimasi, namun harus dilakukan pengujian asumsi klasik terlebih dulu (Ghozali, 2012). Asumsi klasik yang dianggap penting untuk diuji adalah :

\section{a. Uji Normalitas}

Uji normalitas untuk menguji apakah dalam model regresi, variabel dependen dan variabel independen mempunyai kontribusi atau tidak normal. Uji ini perlu dilakukan karena semua perhitungan statistik parametrik memiliki asumsi normalitas sebaran. Model regresi yang baik adalah memiliki distribusi normal atau mendekati normal. Dalam penelitian ini, untuk mendeteksi normalitas data dapat dilakukukan dengan uji scatterplot dengan pedoman adalah :

1) Jika nilai signifikan $\geq 0,05$ maka distribusi normal

2) Jika nilai signifikan $<0,05$ maka distribusi tidak normal 
b. Uji Multikolinearitas

Uji multikolinearitas untuk menguji apakah model regresi terdapat korelasi antar variabel bebas. Model regresi yang baik seharusnya tidak terjadi korelasi yang kuat antar variabel bebas. Untuk mengetahui uji multikolinearitas dengan melihat nilai tolerance dan VIF (Variance Inflation Factor). Apabila nilai tolerance lebih dari 0,1 dan VIF kurang dari 10 maka pada masingmasing variabel tidak terjadi multikolinearitas.

c. Uji Heteroskedastisitas

Uji heteroskedastisitas bertujuan menguji apakah dalam model regresi terjadi ketidaksamaan variance dari residual suatu pengamatan ke pengamatan lain tetap, maka disebut homoskedastisitas. Jika berbeda maka terjadi heteroskedastisitas. Model regresi yang baik adalah homoskedastisitas. Untuk mengetahui ada atau tidaknya gejala ini, digunakan scatter plot dalam formulasi regresi.

\section{Uji Hipotesis}

Uji hipotesis dilakukan untuk mengeta-hui ada tidaknya pengaruh variabel bebas terhadap variabel terikat. Pengujian terhadap hipotesis yang diajukan dalam penelitian ini adalah :

\section{a. Uji t}

Uji t dilakukan untuk mengetahui pengaruh variabel independen $(\mathrm{X})$ yaitu kompetensi, penempatan kerja dan prestasi kerja terhadap variabel dependen (Y) pengembangan karir. Uji t dilakukan dengan membandingkan antara nilai $t$ hitung dengan $\mathrm{t}$ tabel.

b. Uji F

Uji $F$ dilakukan untuk mengetahui pengaruh variabel independen kompetensi, penempatan kerja dan prestasi kerja secara bersama-sama (simultan) terhadap variabel dependen pengembangan karir.

\section{HASIL DAN PEMBAHASAN}

\section{Analisis Deskriptif}

Responden dalam penelitian ini adalah seluruh pegawai Badan Pertanahan Nasional Kota Madiun berjumlah 40 orang yang berstatusASN (Aparatur Sipil Negara). Dalam penelitian ini terdapat empat karateristik yaitu: usia, jenis kelamin, pendidikan terakhir dan masa kerja.

\section{Usia Responden}

Tabel berikut memberikan gambaran responden berdasarkan usia:

Tabel 1

Karakter Responden Berdasarkan Usia Tahun 2019

\begin{tabular}{|c|c|c|}
\hline Usia & Jumlah & Prosen \\
\hline $21-30$ & 6 & $15 \%$ \\
\hline $31-40$ & 10 & $25 \%$ \\
\hline $41-50$ & 9 & $22,5 \%$ \\
\hline$>50$ & 15 & $37,5 \%$ \\
\hline Jumlah & 40 & $100 \%$ \\
\hline
\end{tabular}

Sumber: Data primer diolah

Berdasarkan Tabel 1 dapat diambil kesimpulan bahwa sebagian besar pegawai yang menjadi responden dalam penelitian ini berusia lebih dari 50 tahun, yaitu sebanyak 15 orang responden atau $37,5 \%$.

\section{Jenis Kelamin Responden}

Tabel berikut memberikan gambaran responden berdasarkan jenis kelamin: 
Tabel 2

Karakter Responden Berdasarkan

Jenis Kelamin

Tahun 2019

\begin{tabular}{|l|c|l|}
\hline Jenis Kelamin & Jumlah & Prosen \\
\hline Laki-laki & 15 & $37,5 \%$ \\
\hline Perempuan & 25 & $62,5 \%$ \\
\hline Jumlah & 40 & $100 \%$ \\
\hline
\end{tabular}

Sumber: Data primer diolah

Berdasarkan Tabel 2 dapat diambil kesimpulan bahwa responden dalam penelitian ini sebagian besar adalah perempuan yaitu sebanyak 25 orang atau $62,5 \%$.

\section{Jenjang Pendidikan Responden}

Tabel berikut memberikan gambaran responden berdasarkan jenjang pendidikan:

Tabel 3

Karakter Responden Berdasarkan Jenjang Pendidikan

Tahun 2019

\begin{tabular}{|c|c|c|}
\hline $\begin{array}{c}\text { Jenjang } \\
\text { Pendidikan }\end{array}$ & Jumlah & Prosen \\
\hline SLTA & 14 & $35 \%$ \\
\hline D3 & 4 & $10 \%$ \\
\hline S1 & 12 & $30 \%$ \\
\hline Pascasarjana & 10 & $25 \%$ \\
\hline Jumlah & 40 & $100 \%$ \\
\hline
\end{tabular}

Sumber: Data primer diolah

Berdasarkan Tabel 3 dapat diambil kesimpulan bahwa sebagian besar pegawai yang menjadi responden menamatkan jenjang pendidikan SLTA sebanyak 14 orang atau $35 \%$.

\section{Masa Kerja Responden}

Tabel berikut memberikan gambaran karateristik responden berdasarkan masa kerja:
Tabel 4

Karakter Responden Berdasarkan

Masa Kerja

Tahun 2019

\begin{tabular}{|c|c|c|}
\hline Masa Kerja & Jumlah & Prosen \\
\hline $1-10$ & 10 & $25 \%$ \\
\hline $11-20$ & 8 & $20 \%$ \\
\hline $21-30$ & 7 & $17,5 \%$ \\
\hline $31-40$ & 15 & $37,5 \%$ \\
\hline Jumlah & 40 & $100 \%$ \\
\hline
\end{tabular}

Sumber: Data primer diolah

Tabel 4 menunjukkan bahwa jumlah responden paling banyak memiliki masa kerja 31- 40 tahun yakni sebanyak 15 orang atau $37,5 \%$.

\section{Analisis Kuantitatif}

a. Uji Validitas

Hasil pengolahan data uji validitas pada masing-masing variabel adalah sebagai berikut :

\section{Kompetensi (X1)}

Hasil pengolahan data item pernyataan variabel Kompetensi dapat dilihat pada tabel berikut:

Tabel 5

Uji Validitas Kompetensi (X1)

\begin{tabular}{|c|c|c|c|}
\hline Pernyataan & R hitung & R tabel & Keterangan \\
\hline X1.1 & 0,651 & 0,312 & Valid \\
\hline X1.2 & 0,605 & 0,312 & Valid \\
\hline X1.3 & 0,560 & 0,312 & Valid \\
\hline X1.4 & 0,335 & 0,312 & Valid \\
\hline X1.5 & 0,429 & 0,312 & Valid \\
\hline X1.6 & 0,542 & 0,312 & Valid \\
\hline X1.7 & 0,480 & 0,312 & Valid \\
\hline X1.8 & 0,420 & 0,312 & Valid \\
\hline
\end{tabular}

Sumber:Output SPSS 23

Berdasarkan hasil uji validitas indikator kompetensi (X1) diketahui bahwa semua item pernyataan menunjukkan hasil bahwa nilai $r$ hitunglebih besar dari $r$ tabel.Dengan demikian dapat disimpulkan bahwa masingmasing item pernyataan adalah valid. 


\section{Penempatan Kerja (X2)}

Hasil pengolahan data item pernyataan variabel Penempatan Kerja dapat dilihat pada tabel berikut ini:

\section{Tabel 6}

Uji Validitas Penempatan Kerja (X2)

\begin{tabular}{|c|c|c|c|}
\hline Pernyataan & R hitung & R tabel & Keterangan \\
\hline X2.1 & 0,548 & 0,312 & Valid \\
\hline X2.2 & 0,567 & 0,312 & Valid \\
\hline X2.3 & 0,408 & 0,312 & Valid \\
\hline X2.4 & 0,563 & 0,312 & Valid \\
\hline X2.5 & 0,755 & 0,312 & Valid \\
\hline X2.6 & 0,613 & 0,312 & Valid \\
\hline
\end{tabular}

Sumber:Output SPSS 23

Berdasarkan hasil uji validitas indikator penempatan kerja (X2) diketahui bahwa semua item pernyataan menunjukkan hasil bahwa nilai $r$ hitung lebih besar dari $r$ tabel.Dengan demikian dapat disimpulkan masing-masing item pernyataan adalah valid.

\section{Prestasi Kerja (X3)}

Hasil pengolahan data item pernyataan variabel Prestasi Kerja (X3) dapat dilihat pada tabel berikut ini:

\section{Tabel 7}

Uji Validitas Prestasi Kerja (X3)

\begin{tabular}{|c|c|c|c|}
\hline Pernyataan & R hitung & R tabel & Keterangan \\
\hline X3.1 & 0,582 & 0,312 & Valid \\
\hline X3.2 & 0,541 & 0,312 & Valid \\
\hline X3.3 & 0,602 & 0,312 & Valid \\
\hline X3.4 & 0,659 & 0,312 & Valid \\
\hline X3.5 & 0,791 & 0,312 & Valid \\
\hline X3.6 & 0,654 & 0,312 & Valid \\
\hline X3.7 & 0,709 & 0,312 & Valid \\
\hline X3.8 & 0,641 & 0,312 & Valid \\
\hline
\end{tabular}

Sumber:Output SPSS 23

Berdasarkan hasil uji validitas indikator variabel Prestasi Kerja (X3) diketahui bahwa semua item pernyataan menunjukkan hasil bahwa nilai $r$ hitung lebih besar dari $r$ tabel.Dengan demikian dapat disimpulkan masingmasing item pernyataan adalah valid.

\section{Pengembangan Karir Pegawai (Y)}

Hasil pengolahan data item pernyataan variabel Pengembangan Karir Pegawai dapat dilihat pada tabel berikut ini:

\section{Tabel 8}

Uji Validitas Pengembangan Karir (Y)

\begin{tabular}{|c|c|c|c|}
\hline Pernyataan & R hitung & R tabel & Keterangan \\
\hline Y.1 & 0,629 & 0,312 & Valid \\
\hline Y.2 & 0,641 & 0,312 & Valid \\
\hline Y.3 & 0,568 & 0,312 & Valid \\
\hline Y.4 & 0,395 & 0,312 & Valid \\
\hline Y.5 & 0,519 & 0,312 & Valid \\
\hline Y.6 & 0,528 & 0,312 & Valid \\
\hline Y.7 & 0,486 & 0,312 & Valid \\
\hline Y.8 & 0,497 & 0,312 & Valid \\
\hline
\end{tabular}

Sumber:Output SPSS 23

Berdasarkan hasil pengujian validitas indikator variabel Pengembangan Karir Pegawai (Y) diketahui bahwa semua item pernyataan menunjukkan hasil bahwa nilai $r$ hitung lebih besar dari $r$ tabel.Dengan demikian dapat disimpulkan masing-masing item pernyataan adalah valid.

\section{b. Uji Reliabilitas}

Butir pernyataan dikatakan reliabel apabila jawaban responden terhadap pernyataan adalah konsisten.

Pengujian dilakukan dengan menggunakan Cronbach alpha.Suatu konstruk dikatakan reliabel apabila Cronbach alpha lebih besar dari 0,6.

\section{Tabel 9}

Uji Reliabilitas

\begin{tabular}{|c|c|c|c|}
\hline Variabel & Nilai Kritis & Cronbach $\alpha$ & Keterangan \\
\hline $\mathrm{X} 1$ & 0,6 & 0,612 & Reliabel \\
\hline $\mathrm{X} 2$ & 0,6 & 0,632 & Reliabel \\
\hline $\mathrm{X} 3$ & 0,6 & 0,625 & Reliabel \\
\hline $\mathrm{Y}$ & 0,6 & 0,619 & Reliabel \\
\hline
\end{tabular}

Sumber: Output SPSS 23

Berdasarkan hasil Tabel 9 diketahui bahwa item pernyataan kuesioner yang merupakan pengembangan indikator setiap variabel adalah reliabel. Hal ini dapat dilihat dari Cronbach alpha hitung masing-masing variabel lebih besar dari 0,6 . 


\section{Hasil Analisis Regresi Linier}

Hasil perhitungan regresi pengaruh antara variabel Kompetensi (X1), Penempatan Kerja (X2), dan Prestasi Kerja (X3) sebagai variabel independen terhadap Pengembangan Karirsebagai variabel dependen (Y) dapat dilihat pada Tabel 10 :

Tabel 10

Hasil Analisis Regresi Liniear Coefficients $^{\mathrm{a}}$

\begin{tabular}{|c|c|r|r|r|c|}
\hline \multirow{2}{*}{ Model } & \multicolumn{2}{|l|}{$\begin{array}{c}\text { Unstandardized } \\
\text { Coeff }\end{array}$} & $\begin{array}{c}\text { Standardiz } \\
\text { ed Coeff }\end{array}$ & \multirow{2}{*}{$\mathrm{t}$} & \multirow{2}{*}{ Sign } \\
\cline { 2 - 4 } & $\mathrm{B}$ & \multicolumn{1}{|c|}{ SE } & Beta & & \\
\hline Constant & 1.648 & 1.254 & & 1.314 & .197 \\
\hline $\mathrm{X} 1$ & 1.107 & .143 & 1.255 & 2.768 & .000 \\
\hline $\mathrm{X} 2$ & 9.031 & .056 & .518 & 1.554 & .003 \\
\hline $\mathrm{X} 3$ & 5.267 & .163 & .264 & 3.633 & .001 \\
\hline
\end{tabular}

a. Depend. Var.: Pengembangan Karir Pegawai

\section{Sumber:Output SPSS 23}

Berdasarkan hasil regresi pada Tabel 10 dapat diformulasikan persamaan regresi sebagai berikut :

$$
\mathrm{Y}=1,648+1,107 \mathrm{X} 1+9,031 \mathrm{X} 2+5,267 \mathrm{X} 3
$$

Berdasarkan persamaan regresi linear tersebut, dapat diinterprestasikan

$$
\begin{array}{ccccc} 
& & \multicolumn{2}{c}{\mathrm{R}} & \multicolumn{2}{c}{\text { Adjusted R Std. Error }} \\
\text { Model } & \mathrm{R} & \text { Square } & \text { Square } & \text { Estimate } \\
1 & .986^{\mathrm{a}} & .973 & .706 & .662
\end{array}
$$

beberapa hal sebagai berikut:

a. Nilai konstanta sebesar 1,648 menunjukkan bahwa jika kompetisi, penempatan kerja, dan prestasi tidak dilaksanakan, maka pengembangan karir pegawai pada Kantor BPN Kota Madiun akan meningkat sebesar 1,648 satuan.

b. Koefisien regresi variabel Kompetensi (X1) sebesar 1,107 menunjukkan bahwa jika kompetensi meningkat sebesar 1 satuan maka pengembangan karir pegawai akan meningkat sebesar 1,107 satuan dengan asumsi bahwa variabel penempatan kerja dan prestasi kerja tetap/ tidak berubah.

c. Koefisien regresi variabel Penempatan Kerja (X2) sebesar 9,031 menunjukkan bahwa apabila penempatan kerja meningkat sebesar 1 satuan maka pengembangan karir pegawai akan meningkat sebesar sebesar 9,031 dengan asumsi bahwa variabel kompetensi dan prestasi kerja tetap/ tidak berubah.

d. Koefisien regresi variabel Prestasi Kerja (X3) sebesar 5,267 menunjukkan bahwa apabila prestasi kerja meningkat sebesar 1 satuan maka pengembangan karir pegawai akan meningkat sebesar 5,267 satuandengan asumsi bahwa variabel kompetensi dan penempatan kerja tetap/ tidak berubah.

Koefisien Determinasi $\left(\mathrm{R}^{2}\right)$

Koefisien Determinasi $\left(\mathrm{R}^{2}\right)$ digunakan untuk mengukur seberapa jauh kemampuan model dalam menerangkan variasi variabel dependen. Hasil analisis koefisien determinasi dapat dilihat pada Tabel 11:

Tabel 11

Koefisien Determinasi

Model Summary ${ }^{\mathrm{b}}$

a. Predictors: (Constant), PrestasiKerja,

PenempatanKerja, Kompetensi

b. Dependent Var.: Pengembangan Karir

Sumber :Output SPSS 23

Berdasarkan Tabel 11 diketahui bahwa nilai koefisien determinasi $\left(\mathrm{R}^{2}\right)$ sebesar 0,973 berarti bahwa kompetensi, penempatan kerja dan prestasi kerja berkontribusi sebesar $97,3 \%$ terhadap pengembangan karir pegawai. Sedangkan sisanya $2,7 \%$ dipengaruhi oleh variabel lain yang tidak diteliti. 


\section{Uji Asumsi Klasik}

a. Uji Normalitas

Uji normalitas dilakukan untuk menguji model regresi berdistribusi normal atau tidak (Ghozali, 2009). Pengujian dilakukan dengan menggunakan program SPSS 23 dengan hasil berikut ini:

Gambar 1. Uji Normalitas

\section{Sumber: Output SPSS}

Berdasarkan Gambar 1 normal probability plot menunjukkan titik-titik menyebar di sekitar garis diagonal. Hal ini menunjukkan data variabel dalam penelitian berdistribusi normal.

b. Uji Multikoliniearitas

Uji multikoliniearitas digunakan untuk menguji adakah kolerasi antar variabel independen. Apabila variabel independen memiliki nilai tolerance $>0,10$ atau $\mathrm{VIF}<10$, dapat disimpulkan bahwa tidak ada multikoliniearitas antar variabel independen dalam model regresi.

Tabel 12

Uji Multikolinearitas Coefficients $^{a}$

\begin{tabular}{|l|c|c|}
\hline \multirow{2}{*}{\multicolumn{1}{|c|}{ Model }} & \multicolumn{2}{|c|}{ Collinearity Statistics } \\
\cline { 2 - 3 } & Tolerance & VIF \\
\hline Kompetensi & .029 & 4.636 \\
\hline Penempatan Kerja & .716 & 1.398 \\
\hline PrestasiKerja & .029 & 4.757 \\
\hline
\end{tabular}

a. Dependent Var.: Pengembangan Karir Sumber:Output SPSS 23

Berdasarkan Tabel 12 nilai tolerance dan VIF semua variabel memenuhi syarat. Hal tersebut menunjukkan bahwa tidak ada multikolinieritas antar variabel independen dalam penelitian ini. Kompetensi (X1) memiliki nilai Tolerance 0, $029>0,10$ dan VIF 4,636 < 10; Penempatan Kerja (X2) memiliki nilai Tolerance $0,716>0,10$ danVIF $1,398<10$ dan Prestasi Kerja (X3) memiliki nilai Tolerance 0, $029>0,10$ dan VIF 4,757. Dari hasil tersebut dapat disimpulkan bahwa variabel independen dalam penelitian ini tidak terjadi multikolinieritas.

c. Uji Heteroskedastisitas

Uji heteroskedastisitas digunakan untuk mengetahui ada tidaknya ketidaksamaan varian residual variabel pada model regresi. Prasyarat yang harus terpenuhi adalah homoskedastisitas. Hasil uji heteroskedastisitas dengan program dapat dilihat pada gambar berikut :

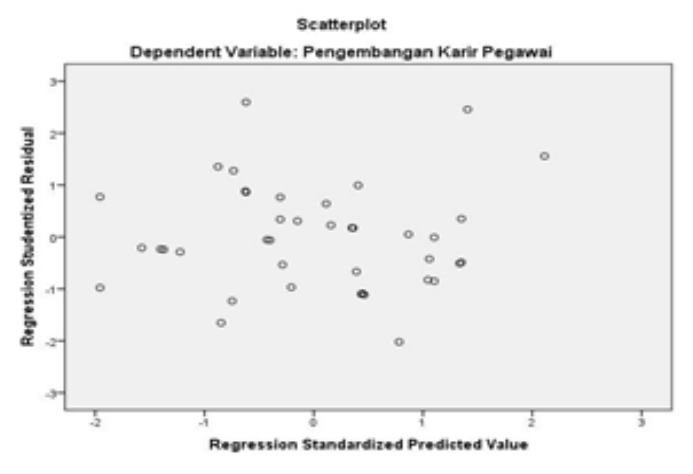

Gambar 2. Uji Heteroskedastisitas

Sumber:Output SPSS 23

Dasar pengambilan keputusan adalah :

1. Jika ada titik-titik (poin) yang membentuk suatu pola tertentu yang teratur (bergelombang, melebar, kemudian menyempit), maka telah terjadi heteroskedastisitas.

2. Jika tidak ada yang jelas, serta titik menyebar di atas, di bawah angka nol dan dibawah sumbu $\mathrm{Y}$, maka tidak terjadi heteroskedastisitas.

Berdasarkan Gambar 2, dapat dilihat bahwa tingkat penyebaran data dalam penelitian, menyebar di atas dan di bawah angka nol di bawah sumbu Y. Hal ini menunjukkan bahwa tidak terjadi heteroskedastisitas. 


\section{Hasil Uji Hipotesis}

Pengujian hipotesis mutlak dilakukan untuk membuktikan apakah terdapat pengaruh signifikan variabel Kompetensi (X1), Penempatan Kerja (X2), Prestasi Kerja (X3) terhadap Pengembangan Karir Pegawai (Y) pada Kantor Badan Pertanahan Nasional Kota Madiun.

a. Uji t

Uji t digunakan untuk mengetahui ada atau tidaknya pengaruh variabel independen secara parsial terhadap variabel dependen. Hasilnya telah disajikan pada Tabel 10.

Uji t dilakukan dengan membandingkan nilai $\mathrm{t}$ hitung dengan $\mathrm{t}$ tabel masing-masing variabel. Jumlah sampel (n) 40 dan jumlah seluruh variabel (k) adalah 4, df (degree of freedom) adalah $\mathrm{n}-\mathrm{k}=40-4=36$ dengan tingkatsignifikansi 5\%. Maka $t_{\text {tabel }}$ adalah sebesar 2,028 .

Berdasarkan hasil perhitungan dalam Tabel 10, variabel Kompetensi diperoleh thitungsebesar 2,768 lebih besar dari $t$ tabel 2,028, maka Ho ditolak dan Ha diterima.

Hal ini berarti ada pengaruh signifikan kompetensi terhadap pengembangan karir pegawai pada Kantor BadanPertanahan Nasional Kota Madiun.

Variabel Penempatan Kerja diperoleh thitungsebesar 1,554 lebih kecil dari $t$ tabel 2,028 maka Ho diterima dan Ha ditolak. Hal ini berarti tidak ada pengaruh penempatan kerja terhadap pengembangan karir pegawai pada Kantor Badan Pertanahan Nasional Kota Madiun.

Variabel Prestasi Kerja diperoleh $\mathrm{t}$ hitung sebesar 3,633 lebih besar dari $\mathrm{t}$ tabel 2,028, maka Ho ditolak dan $\mathrm{Ha}$ diterima. Hal ini berarti terdapat pengaruh signifikan prestasi kerja terhadap pengembangan karir pegawai pada Kantor Badan Pertanahan Nasional Kota Madiun.

b. Uji F

Uji $F$ digunakan untuk mengetahui pengaruh variabel independen dalam model regresi secara bersama-sama terhadap variabel dependen yang diuji pada tingkat signifikan 0,05 . Hasil analisis uji $\mathrm{F}$ hitung dapat dilihat pada tabel berikut ini :

Tabel 13

Uji F (Uji Simultan)

ANOVA $^{\mathrm{a}}$

\begin{tabular}{|c|r|r|r|c|c|}
\hline Model & $\begin{array}{c}\text { Sum of } \\
\text { Squares }\end{array}$ & df & $\begin{array}{c}\text { Mean } \\
\text { Square }\end{array}$ & F & Sign \\
\hline Regression & 566.11 & 3 & 188.70 & 43.18 & $.00^{\mathrm{b}}$ \\
\hline Residual & 15.79 & 36 & .44 & & \\
\hline Total & 581.90 & 39 & & & \\
\hline
\end{tabular}

a. Dependent Var.: Pengembangan Karir

b. Predictors: (Constant), Prestasi Kerja, PenempatanKerja, Kompetensi

Sumber: Output SPSS 23

Untuk melakukan uji $\mathrm{F}$, harus membandingkan nilai $\mathrm{F}$ hitung dengan $\mathrm{F}$ tabel. Diketahui jumlah sampel (n) adalah 40 dan jumlah seluruh variabel (k) adalah 4. Maka df nilai $\mathrm{F}$ tabel yaitu $\mathrm{v} 1=\mathrm{n}-\mathrm{k}=40-4=36$, dan $\mathrm{v} 2=\mathrm{k}-$ $1=4-1=3$ dengan tingkat signifikansi $5 \%$. Nilai $F$ tabel sebesar 2,87.

1. Jika $\mathrm{F}$ hitung < $\mathrm{F}$ tabel, Ho diterima artinya tidak ada pengaruh antara variabel Kompetensi (X1), Penempatan Kerja (X2) dan Prestasi Kerja (X3) dengan variabel terikat Pengembangan Karir Pegawai (Y).

2. Jika $F$ hitung $\geq F$ tabel, Ho ditolak artinya ada pengaruh variabel Kompetensi (X1), Penempatan Kerja (X2) dan Prestasi Kerja (X3) secara 
simultan/ bersama-sama terhadap variabel Pengembangan Karir (Y).

Berdasarkan hasil perhitungan pada Tabel 13 diperoleh nilai $F$ hitung $(43,811)$ lebih besar dari F tabel $(2,87)$, maka Ho ditolak dan Ha diterima. Hal ini berarti terdapat pengaruh simultan/bersama-sama kompetensi, penempatan kerja dan prestasi kerja terhadappengembangan karir pegawai pada Kantor Badan Pertanahan Nasional Kota Madiun.

\section{PEMBAHASAN}

1. Karakteristik Responden

Berdasarkan hasil penelitian dapat diketahui bahwa karateristik responden yakni pegawai Kantor Badan Pertanahan Nasional Kota Madiun adalah :

a. Sebagian besar responden berusia lebih dari 50 tahun.

b. Sebagian besar responden adalah perempuan.

c. Sebagian besar responden memiliki jenjang pendidikan SLTA.

d. Sebagian besar responden memiliki masa kerja 31- 40 tahun.

2. Pengaruh Kompetensi, Penempatan Kerja dan Prestasi Kerja terhadap Pengembangan Karir Pegawai

a. Kompetensi

Kompetensi berpengaruh secara nyata terhadap pengembangan karir pegawai pada Kantor Badan Pertanahan Nasional Kota Madiun. Hasil penelitian ini sesuai dengan penelitian yang dilakukan oleh Wirotomo (2015) yang menyatakan bahwa kompetensi berpengaruh terhadap pengembangan karir pegawai. Hal ini menunjukkan bahwa pegawai yang mempunyai kompetensi, memiliki kemampuan kerja lebih baik karena pegawai tersebuttelah menguasai pekerjaan dan memiliki keterampilan yang lebih optimal.Pegawai tersebut mampu menghadapi permasalahan yang timbul dalam pekerjaan.Dengan didukung oleh kompetensi yang sesuai, dapat menunjang pengembangan diri dalam perubahan yang ada.

b. Penempatan Kerja

Penempatan kerja tidak berpengaruh terhadap pengembangan karir pegawai pada Kantor Badan Pertanahan Nasional Kota Madiun. Penelitian ini tidak sesuai dengan penelitian yang dilakukan oleh Astuti (2018) yang menyatakan, bahwa penempatan kerja berpengaruh terhadap kinerja karyawan.Hal ini menunjukkan bahwa penempatan kerja dalam institusi kurang mendapatkan perhatian, karena ditempatkan di bagian apapun pegawai dituntut untuk mampu menyesuaikan dan melaksanakan tugas dengan baik sesuai dengan aturan yang telah ditetapkan sebelumnya. Tidak ada aturan bahwa dalam menjalankan tugas harus sesuai dengan porsi dan kapasitas pegawai tersebut atau dengan kata lain pegawai harus bisa mengerjakan semua pekerjaan meski tidak sesuai bidangnya.

Seyogyanya penempatan kerja harus mendapatkan perhatian lebih baik, karena penempatan kerja bagi pegawai dapat menunjang efisiensi dan efektifitas kerjaserta membuat pegawai merasa nyaman dalam bekerja.

c. Prestasi Kerja

Prestasi kerja berpengaruh secara nyata terhadap pengembangan karir 
pegawai pada Kantor Badan Pertanahan Nasional Kota Madiun. Hal ini sesuai dengan penelitian oleh Tendean (2017) yang menyatakan bahwa prestasi kerja berpengaruh terhadap pengembangan karir pegawai. Hal ini menunjukkan bahwa prestasi kerja dibutuhkan dalam mencapai karir yang lebih baik. Prestasi kerja yang baik, akan menunjukkan kinerja terbaik pegawai sesuai dengan yang dibutuhkan oleh institusi dan pasti akan berpengaruh langsung terhadap karir pegawai tersebut kedepannya. Proses pengembangan karir yang efektif akan mampu memberikan kesempatan bagi pegawai menyesuaikan dengan kesempatan karir yang tersedia.

Berdasarkan hasil analisis menunjukan bahwa kompetensi, penempatan kerja dan prestasi kerja secara bersama-sama atau secara simultan berpengaruh terhadap pengembangan karir pegawai pada Kantor Badan Pertanahan Nasional Kota Madiun. Penelitian ini sesuai dengan penelitian oleh Paseki (2015) yang menyatakan bahwa kompetensi, penempatan kerja dan prestasi kerja secara simultan berpengaruh terhadap pengembangan karir pegawai.

\section{SIMPULAN}

Berdasarkan hasil analisis pengaruh kompetensi, penempatan kerja dan prestasi kerja terhadap pengembangan karir pegawai di Kantor Badan Pertanahan Nasional Kota Madiun dapat diambil kesimpulan sebagai berikut:

1. Kompetensiberpengaruh positif dan nyata terhadap pengembangan karir pegawai pada Kantor Badan Pertanahan Nasional Kota Madiun.
2. Penempatan kerja tidak berpengaruh terhadap pengembangan karir pegawai pada Kantor Badan Pertanahan Nasional Kota Madiun.

3. Prestasi kerja berpengaruh positif dan nyata terhadap pengembangan karir pegawai pada Kantor Badan Pertanahan Nasional Kota Madiun.

4. Kompetensi, penempatan kerja, dan prestasi kerja secara bersama-sama berpengaruh nyata terhadap pengembangan karir pegawai pada Kantor Badan Pertanahan Nasional Kota Madiun.

Berdasarkan kesimpulan, disampaikan beberapa saran berikut :

1. Dalam upaya meningkatkan karir pegawai, Kantor Badan Pertanahan Nasional Kota Madiun hendaknya mampu memberikan dorongan yang lebih baik melaluiberbagai aspek bukan hanya kompetensi, alokasi penempatan kerja dan prestasi kerja saja. Hendaknya juga berusaha meningkatkan keterampilan pegawai, sehingga kompetensi setiap pegawai dapat ditingkatkan lebih baik.

2. Kantor Badan Pertanahan Nasional Kota Madiun perlu meningkatkan prestasi kerja pegawai guna menunjang karir di waktu yang akan datang.

3. Kantor Badan Pertanahan Nasional Kota Madiun hendaknya secara kontinyu melakukan evaluasi kerja serta melaksanakan program pendidikan dana tau pelatihan yang dapat mendukung pengembangan karir pegawai sehingga meminimalkan pegawai yang tidak kompeten.

4. Dalam penempatan kerja hendaknya Kantor Badan Pertanahan Nasional Kota Madiun tidak terpaku kepada prestasi akademik pegawai saja, melainkan juga menimbang perihal 
kemampuan, keahlian dan pengalaman yang dimiliki oleh pegawai.

\section{DAFTAR RUJUKAN}

Astuti, M. W. dan Bukhari, E. (2018) 'Analisis Kinerja Pegawai Pt Tirta Investama', JRMSI - Jurnal Riset Manajemen Sains Indonesia, 9(1), pp. 22-36. doi: 10.21009/jrmsi.009.1.02.

Chung, R. G. and L, L. C. (2007) 'The Development of Teamwork Competence Questionare. Using Students Of Business Administration Departmen As An Example', International Journal of Technology and Engineering Education, (March Special Issue), pp. 51-57.

Dessler, G. (2005) Human Resource Management. Internatio. New Jersey: Pearson Education, Inc.

Fitriaty and Ninik, V. (2015) 'Analisis Penempatan Pegawai pada Badan Kepegawaian Pendidikan dan Pelatihan Daerah di Kabupaten Sarolangun Tahun 2013 - 2015', Jurnal Manajemen Terapan dan Keuangan, 4(April), pp. 28-36. Available at: https://onlinejournal.unja.ac.id/index.php/mank eu/issue/view/507.

Ghozali, I. (2012) Aplikasi Analisis Multivariate dengan Program SPSS. Semarang: Badan Penerbit Universitas Diponegoro.

Mulyati, T. (2015) 'Pengaruh Kompetensi, Budaya Akademik dan Kepemimpinan Spiritual Terhadap Motivasi dan Implikasinya', 19(Maret), pp. 6689. Available at: https://ejournal.stiesia.ac.id/ekuita s/article/download/90/85.

Paseki, F. M. (2013) 'Kualitas Kehidupan Kerja dan Kinerja Karyawan Terhadap Pengembangan Karir Pada Kanwil Direktorat Jenderal Kekayaan Negara Suluttenggo Malut di Manado', Jurnal Riset Ekonomi, Manajemen, Bisnis dan Akuntansi, 1(4), pp. 1240-1249. Available at: https://ejournal.unsrat.ac.id/index. php/emba/article/view/2904.

Supardi, E. (2009) 'Pengembangan Karir Kontribusinya Terhadap Kinerja Pegawai', Jurnal Geografi Gea, 9(1). doi: 10.17509/gea.v9i1.1680.

Syaharudin, M., Syah, H. A. and Nurhardjo, B. (2018) 'Pengaruh Pengembangan Karier dan Penilaian Kinerja terhadap Kepuasan Kerja Melalui Komitmen Kerja Karyawan Koperasi Agrobisnis Tarutama Nusantara Jember', e-Journal Ekonomi Bisnis dan Akuntansi, 5(2), p. 158 . doi: 10.19184/ejeba.v5i2.8677.

Wirotomo D. and Novita, P. P. (2015) 'Pengaruh Kompetensi, Pengembangan Karir, Pendidikan dan Pelatihan (Diklat) Terhadap Kinerja Pegawai Direktorat Jenderal Perimbangan Keuangan', Mix, V (3). Available at: http://publikasi.mercubuana.ac.id/ index.php/Jurnal_Mix/article/vie w/630/548. 


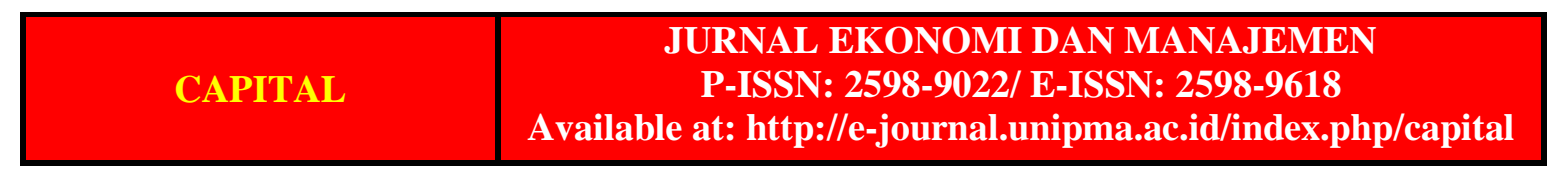

